\title{
Feeding and resource allocation in the mussel Mytilus edulis: evidence for time-averaged optimization
}

\author{
A. J. S. Hawkins ${ }^{1}$, P. N. Salkeld ${ }^{1}$, B. L. Bayne ${ }^{1}$, E. Gnaiger ${ }^{1,2}$ and D. M. Lowe \\ ' Institute for Marine Environmental Research, Prospect Place, The Hoe, Plymouth PL1 3DH, Devon, England \\ ${ }^{2}$ Institut für Zoologie, Abtellung Zoophysiologie, Universität Innsbruck, Peter-Mayr-Str. 1a, A-6020 Innsbruck, Austria
}

\begin{abstract}
Although sustained predominantly by nutrients obtained directly from the environment, metabolic requirements for both gametogenesis and general maintenance in an open-shore population of the bivalve mollusc Mytilus edulis L. from southwest England were also 'subsidized' from substantial energy reserves accumulated during periods of somatic growth. Depletion of these reserves over late winter was associated with a greater sensitivity in the rate of oxidative metabolism to exogenous nutrient availability, diminished metabolic efficiencies with which absorbed ration was utilized, and an associated increase in the instantaneous maintenance requirements. Absorption rates, which were nevertheless minimal during winter, are suggested to be endogenously regulated in a manner more indicative of time-averaged than immediate optimization. It is proposed that such regulation may be especially adaptive within $M$. edulis, a sedentary species that experiences pronounced annual cycles of food availability, and in which costs deriving from feeding and associated activities are shown to add as much as $38 \%$ to standard metabolic demands.
\end{abstract}

\section{INTRODUCTION}

The seasonal nature of gametogenesis and changes in gross biochemical composition among temperate bivalve molluscs have been researched for decades (reviewed by Giese, 1966, 1969; Gabbott, 1975, 1976. 1983; Bayne, 1976; Sastry, 1979). In general, these studies indicate an adaptive ability to synthesize and store lipid, protein and glycogen substrates during periods of surplus nutrient availability. These reserves are subsequently used either to fuel energy demands when food is scarce, or for conversion into lipid within the developing gametes (Gabbott, 1975; Bayne, 1976; Zandee et al., 1980a). The relative importance of each substrate, however, together with their sites of storage and the timing of their utilization, varies on both an inter- and intraspecific basis (Giese, 1969; Bayne, 1976; Sastry, 1979; Barber and Blake, 1981). Contemporary knowledge of such variation among Mytilus edulis alone extends between populations from southwest England (Bayne et al., 1982; Lowe et al., 1982); north Wales (Waldock and Holland, 1979; Lowe et al., 1982); the Dutch Wadden Sea (Pieters et al., 1979, 1980; Zurburg et al., 1979; Zandee et al., 1980a,b) and Norway (Skjoldal and Barkati, 1982).
To achieve further understanding of the adaptations enabling long-term (annual) energy balance in bivalve molluscs, it is essential to apply the techniques of physiological energetics. Fundamental to this approach is the premise that adaptive responses concerning the mechanisms of energy acquisition and expenditure may only be understood upon consideration of the complete energy budget, and in relation to seasonal variations of field-ambient nutrient concentration (Bayne and Newell, 1983). Comprehensive studies of this nature are few, but include research on Mytilus edulis from the Lynher (Bayne and Widdows, 1978; Widdows, 1978a,b) and Plym (Bayne and Widdows, 1978) estuaries in southwest England, and from Trinity Bay in Newfoundland (Thompson, 1984).

Implicit to many of these studies is the assumption that seasonal changes in an organism's energy balance are the direct result of environmental variability in either temperature or, more significantly, in the supply of nutrients. The individual is assumed to maximize energy (or nutrient) gain under all circumstances, when endogenous factors are viewed as affecting only the allocation of nutrients, for example to gametogenesis and/or somatic growth. We were interested in challenging this assumption, choosing to 
ascertain, for the first time, physiological, reproductive and storage cycles in an open-shore population of Mytilus edulis that is naturally subjected to marked seasonal variability in the supply of food. Further, in addition to providing comparative data for assessing the degree of physiological flexibility among $M$. edulis and other bivalves from different environments, this work was intended to investigate seasonal relationships between both metabolic demand and efficiencies.

\section{MATERIALS AND METHODS}

Mytilus edulis L. of 45 to $57 \mathrm{~mm}$ in shell length were gathered at intervals between November 1980 and March 1982 from an open-shore population immediately to the west of Sharrow Point, Whitsand Bay, Cornwall, England. Such collection was always undertaken at about low-water tide level.

The seasonal cycle of gametogenesis was determined by measuring, within mantle tissue, the relative volume fractions of vesicular connective tissue cells, adipogranular cells, and both developing and ripe gametes, according to the stereological methods described by Lowe et al. (1982). In addition, the total soft tissues from groups of 10 to 12 mussels were either excised whole or subdivided into digestive gland, mantle and 'remainder' fractions. Following most seasonal collections, all dissected tissues were dried at $80^{\circ} \mathrm{C}$ for $24 \mathrm{~h}$ prior to weighing. At other times, when elemental analyses were also to be undertaken, only half the tissues from each group were oven-dried as described; the remaining samples were pooled, freezedried and homogeneously powdered before storing at $-90^{\circ} \mathrm{C}$ within airtight glass vials.

Carbon, nitrogen, hydrogen and ash were assayed within aliquots of the freeze-dried and powdered tissues. Ash content was measured in 35 to $240 \mathrm{mg}$ subsamples following combustion by means of electrically excited oxygen (Gleit and Holland, 1962). Atomic composition $(\mathrm{C}, \mathrm{H}, \mathrm{N})$ was then determined for both freeze- dried and ashed sub-samples of 2 to $7 \mathrm{mg}$ in an elemental analyser using acetanilide as a standard.

A stoichiometric concept developed by Gnaiger and Bitterlich (1984), based upon the measured atomic composition of dry organic (ash free) weight, was later employed to predict the caloric content, together with fractions of carbohydrate, lipid and protein within each sub-sample. Predictions were undertaken assuming all nitrogen to be protein-bound, together with a common residual water fraction of 0.06 . Using tissue samples collected during this study, we found that stoichiometrically calculated and biochemically determined proximate biochemical compositions agreed to within $13 \%$ of the ash-free dry weight (Table 1). These direct biochemical analyses were undertaken by Miss. G. Bitterlich (Universität Innsbruck, Austria, using methods described within Gnaiger and Bitterlich [1984]). Mean ranges ( $\pm 2 \mathrm{SE}$ ) of the fractional compositions predicted from each of 3 replicate determinations of atomic composition undertaken upon the same tissue samples $(n=5)$ were as low as $0.017 \pm 0.0004$, $0.015 \pm 0.005$ and $0.015 \pm 0.011$ for protein, lipid and carbohydrate, respectively.

Mussels destined for physiological measurements were cleared of epibiotic growth and transferred to an indoor aquarium of recirculating seawater $(33.0 \pm$ $1.5 \%$ S) regulated to temperatures recorded during acclimation (Fig. 1). Individuals collected in March, June and October 1981 were divided into 2 groups, of which one was fed and the other starved throughout periods of 5 to $6 \mathrm{wk}$ before the determination of physiological condition. For all other seasonal samples, such measurements were only undertaken upon fed individuals, and within 1 wk of collection. When fed, both during acclimation and certain of the subsequent experimental procedures, mussels were supplied with Phaeodactylum tricornutum at ambient cell concentrations between 5 and $10 \times 10^{3}$ cells $\mathrm{cm}^{-3}$. Starved mussels were supplied with filtered seawater, ensuring that ambient concentrations of particles larger than $2 \mu \mathrm{m}$ never exceeded $400 \mathrm{~cm}^{-3}$.

Physiological responses were determined as follows:

Table 1. Mytilus edulis. Comparison of stoichiometrically calculated and biochemically determined proximate biochemical compositions (means for 3 replicate analyses in each case undertaken upon the same homogenate of 5 mussels), expressed as a percentage of the ash-free dry weight of freeze-dried mussels

\begin{tabular}{|c|c|c|c|c|c|c|}
\hline \multirow[t]{2}{*}{ Mussel } & \multicolumn{2}{|c|}{ Carbohydrate } & \multicolumn{2}{|c|}{ Protein } & \multicolumn{2}{|c|}{ Lipid } \\
\hline & Biochemical & Stoichiometric & Biochemical & Stoichiometric & Biochemical & Stoichiometric \\
\hline 1 & 31.9 & 29.7 & 50.7 & 54.7 & 11.4 & 9.6 \\
\hline 2 & 28.2 & 15.3 & 54.5 & 67.4 & 11.3 & 11.3 \\
\hline 3 & 5.7 & 11.1 & 70.7 & 75.9 & 17.6 & 7.0 \\
\hline 4 & 47.9 & 39.1 & 36.3 & 43.6 & 9.7 & 11.3 \\
\hline 5 & 43.8 & 36.8 & 40.7 & 48.3 & 9.4 & 8.8 \\
\hline
\end{tabular}




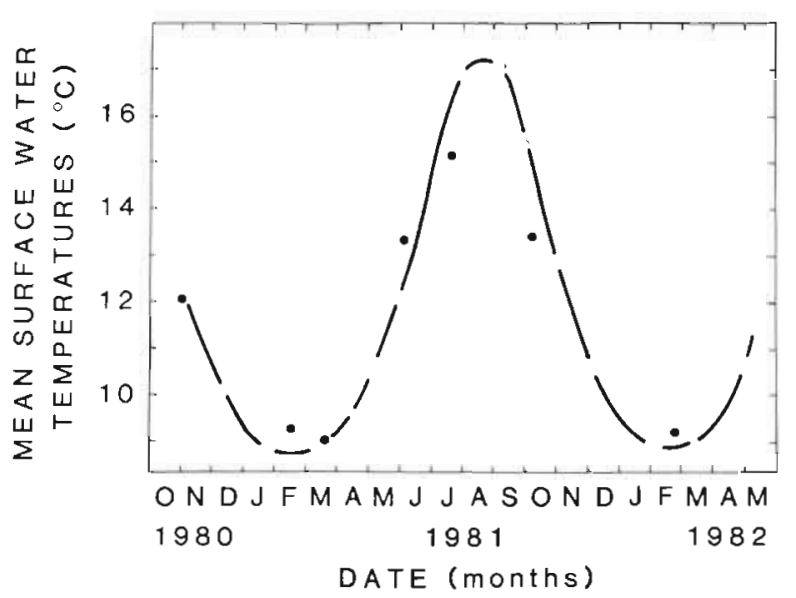

Fig. 1. Seasonal variations in surface water temperature at Whitsand Bay (closed circles, our measurements; open circles, data extrapolated from $5 \mathrm{~d}$ mean isotherms determined by the Meteorological Office) (H. M. S. O. Press, Bracknell)

(1) Rates of oxygen consumption $\left(\dot{N}_{\mathrm{O}_{2}} ; \mu \mathrm{mol} \mathrm{O} \mathrm{O}_{2}{ }^{-1}\right)$ were measured ( $n=5-12$ ) as described by Bayne (1971) and Bayne et al., (1977).

(2) Rates of ingestion (IR; $\mathrm{mg}$ algae $>1.2 \mu \mathrm{m}$ cleared $\mathrm{h}^{-1}$ ) by mussels that had been maintained for less than $1 \mathrm{wk}$ were calculated from the product of algal availability ( $\left.\mathrm{mg} \mathrm{l}^{-1}\right)$ and clearance rates $\left(\mathrm{l} \mathrm{h}^{-1}\right)$. Clearance rates were measured $(n=11$ to 12$)$ as described by Widdows et al., (1981b). Following laboratory acclimation of 5 to $6 \mathrm{wk}$, however, ingestion rate was determined by quantifying the algal input required to sustain constant cell concentrations (cf. method of Winter, 1969; Epifanio and Ewart, 1977; Palmer, 1980) over $6 \mathrm{~h}$ within 22-1 tanks (1 per group) of recirculating seawater, each containing 145 to 150 mussels. Regular corrections restricted unavoidable fluctuations in cell density to within $\pm 20 \%$ of the concentration desired.

(3) Rates of net ammonia excretion $\left(\dot{N}_{\mathrm{NH}_{4}} ; \mu \mathrm{mol} \mathrm{h}^{-1}\right)$ by mussels that had been maintained for less than 1 wk were determined ( $n=11$ to 12 ) as described by Bayne and Scullard (1977a) and Widdows et al. (1981b). The measurement of net ammonia flux by mussels acclimated over 5 to 6 wk during March, June and October 1981 has previously been described by Hawkins et al. (1983); values presented here represent the mean $( \pm 2 \mathrm{SE})$ derived from 40 hourly samples collected from each of 2 replicate groups of 5 individuals.

(4) The efficiency with which mussels absorbed ingested algae (\%) was determined using the ratio method of Conover (1966).

Two condition indices, scope for growth and oxygen to nitrogen ratio, were calculated from measured physiological rates (cf. method of Bayne et al., 1979; Widdows et al., 1981a, b; and those quoted therein). Scope for growth, an indirect measure of production based upon the energy equation of Winberg (1980), makes no distinction between somatic growth and reproductive output (Warren and Davis, 1967), such that:

$$
P=A-(R+U),
$$

where $P=$ production; $A=$ energy absorbed; $R=$ energy respired; $U=$ energy excreted. The calculation of $A, R$ and $U$, all expressed as $\mathrm{J} \mathrm{h}^{-1}$, was as follows:

$A=$ ingestion rate $\left(\mathrm{mg} \mathrm{h}^{-1}\right) \times$ energy content of Phaeodactylum tricornutum (18.1 $\left.\mathrm{J} \mathrm{mg}^{-1}\right) \times$ absorption efficiency;

$R=$ metabolic rate $\left(\mu \mathrm{mol} \mathrm{O}_{2}\right.$ consumed $\left.h^{-1}\right) \times 0.45^{\text {a }}$ $(\mathrm{J} / \mu \mathrm{mol} \mathrm{O})_{\text {; }}$

$U=$ net ammonia excretion $\left(\mu \mathrm{mol} \mathrm{h}^{-1}\right) \times 0.34^{b}(\mathrm{~J} /$ $\mu \mathrm{mol} \mathrm{NH}_{4}$ ).

Energy conversion factors $a$ and $b$ were from Gnaiger (1983) and Elliot and Davison (1975), respectively. The energy content of Phaeodactylum tricornutum was based on a measured organic carbon content of $42.8+0.09 \%( \pm 2 \mathrm{SE}, n=5)$, using the relation described by Salonen et al. (1976; Fig. 1) to compute a value uncorrected for nitrogen. $\mathrm{O}: \mathrm{N}$ ratios were computed as the ratio of oxygen consumed to nitrogen excreted, in atomic equivalents (Corner and Cowey, 1968). Nitrogen quotients, where $N Q=2 / \mathrm{O}: \mathrm{N}$, are presented for comparison.

Although mussels 45 to $57 \mathrm{~mm}$ in length were used for all analyses described above, in July and October 1980, and in November 1982, shell lengths were related to dry flesh weights ( $n=15$ to 18 ) representing the full size range of mussels obtainable. Similar ranges of dry weight were also related to $\dot{N}_{\mathrm{O} 2}$, IR and $\dot{N}_{\mathrm{NH} 4}$ measured during both March and August 1981 among mussels ( $n=19-32$ ) maintained within the laboratory for less than $1 \mathrm{wk}$. Least-squares regression analyses on $\log _{10}$-transformed values of weight (W), length (L) and physiological rates (Y) were carried out, for each sample, according to the allometric equations:

$$
\mathrm{W}=a \cdot \mathrm{L}^{b} \text { and } \mathrm{Y}=\mathrm{a} \cdot \mathrm{W}^{b},
$$

where $a$ and $b=$ fitted parameters representing intercepts and slopes, respectively. Covariance analysis could then be applied to compare estimates of $b$ and $a$. These and all other statistical procedures used in the analysis of data follow Sokal and Rohlf (1969).

\section{RESULTS}

\section{Allometry, tissue weight changes and reproductive cycle}

All regressions of total dry flesh weight ( $W$; $\mathrm{mg}$ ) and shell length $\left(\mathrm{L}_{i} \mathrm{~mm}\right)$ were significant $(P<0.01)$. 


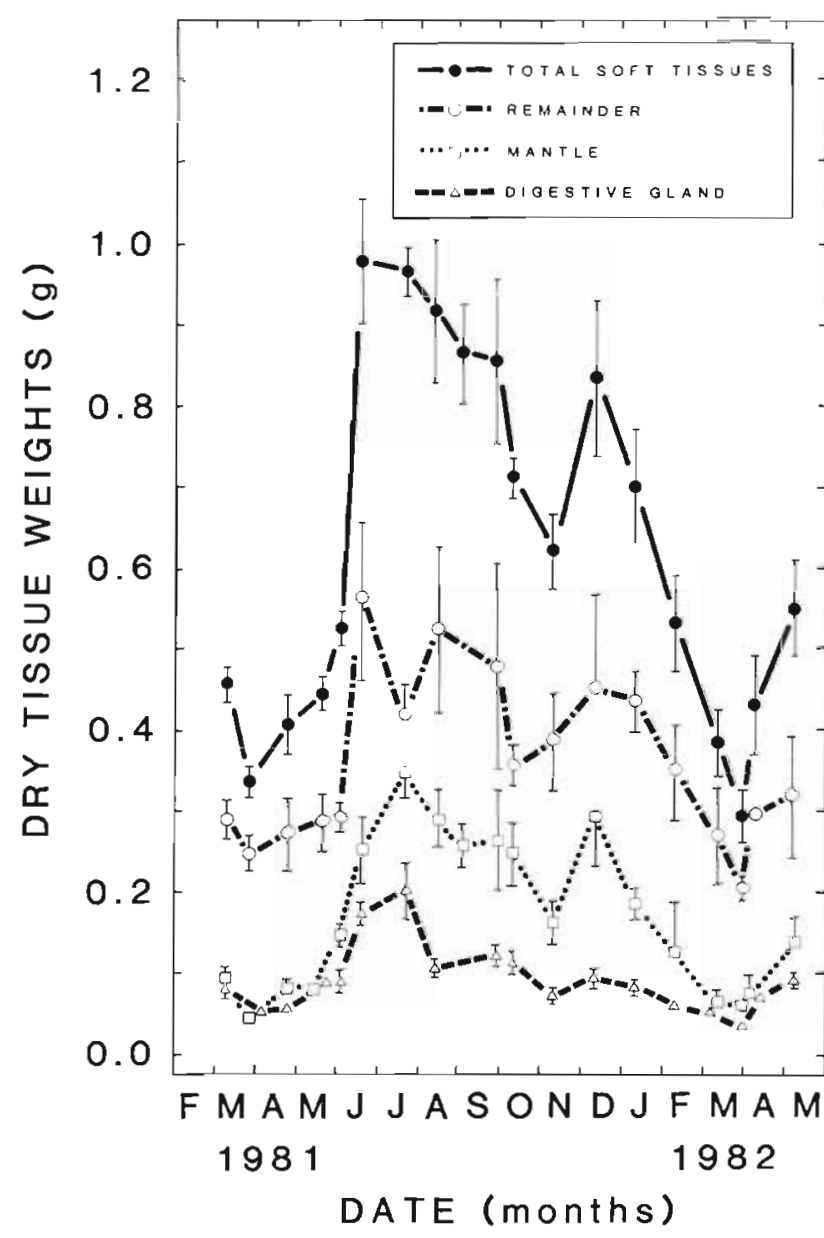

Fig. 2. Mytilus edulis. Seasonal dry weights (mean $\pm 1 \mathrm{SE}$; $n=5-12$ ) of tissues sampled from $50 \mathrm{~mm}$ shell-length mussels. Only standard errors greater than $0.015 \mathrm{mg}$ are indicated

Further, despite clear $(P<0.05)$ seasonal variation of the parameter $a$, covariance analysis showed no significant difference between estimates of slope (b). A common expression:

$$
\mathrm{W}=a . \mathrm{L}^{3.14} \pm 0.21\left(n=56 ; r^{2}=0.94\right),
$$

was accepted, and used to compute seasonal changes in dry tissue weight for a standard animal of $50 \mathrm{~mm}$ shell length (Fig. 2). During such transformations, the percentage contribution of each tissue division towards total dry tissue weight was assumed not to differ between individuals of different size within each seasonal sample. The results indicate pronounced annual cycles, where maximum weights recorded for each tissue division in June/July 1981 were 2 to 7 times greater than the minima recorded in March of both 1981 and 1982

To account for seasonal fluctuation in mantle size, and thus facilitate interpretation of the reproductive cycle, data for volume fractions of the various components of this tissue (Fig. 3) were transformed to tissue

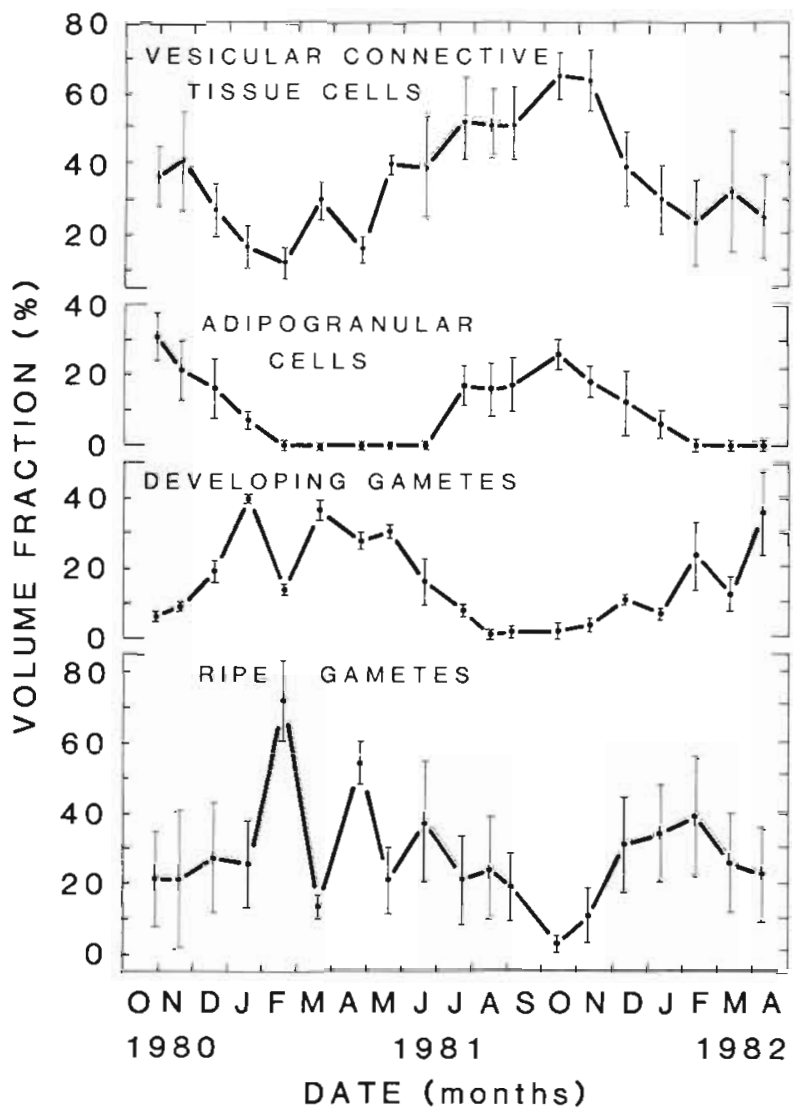

Fig. 3. Mytilus edulis. Seasonal volume fractions (mean $\pm 2 \mathrm{SE} ; n=10$ ) of mantle tissue components in $45-57 \mathrm{~mm}$ shell-length mussels. Only standard errors greater than $2 \%$ are indicated

weight equivalents for mussels of $50 \mathrm{~mm}$ shell length (Fig. 4). Seasonal comparison on this basis, for individual tissues, assumes constant densities over time.

The overall reproductive pattern shown in Fig. 3 and 4 is similar to that described for Mytilus edulis by Chipperfield (1953) and Lubet (1959). In addition, successive periods of spawning in spring and autumn were representative of cycles recorded among mussels from the Dutch Wadden Sea (Pieters et al., 1980), Lynher estuary (S.W. England; Lowe et al., 1982) and elsewhere (reviewed by Seed, 1976). Mussels from Whitsand Bay were largely in the resting and early development phase during October/November of 1980 and 1981, followed by increasing gamete development through to mid winter. Declines in the volume fraction and weight of ripe gametes indicated that spawning occurred between December and March of both 1981 and 1982. Similarly, changing weights of both ripe and developing gametes showed that during 1981 a period of rapid gamete maturation, interspersed by a minor spawning in April/May, then occurred until June. This was followed by a main summer spawning lasting to October, and a subsequent return to the resting phase. 


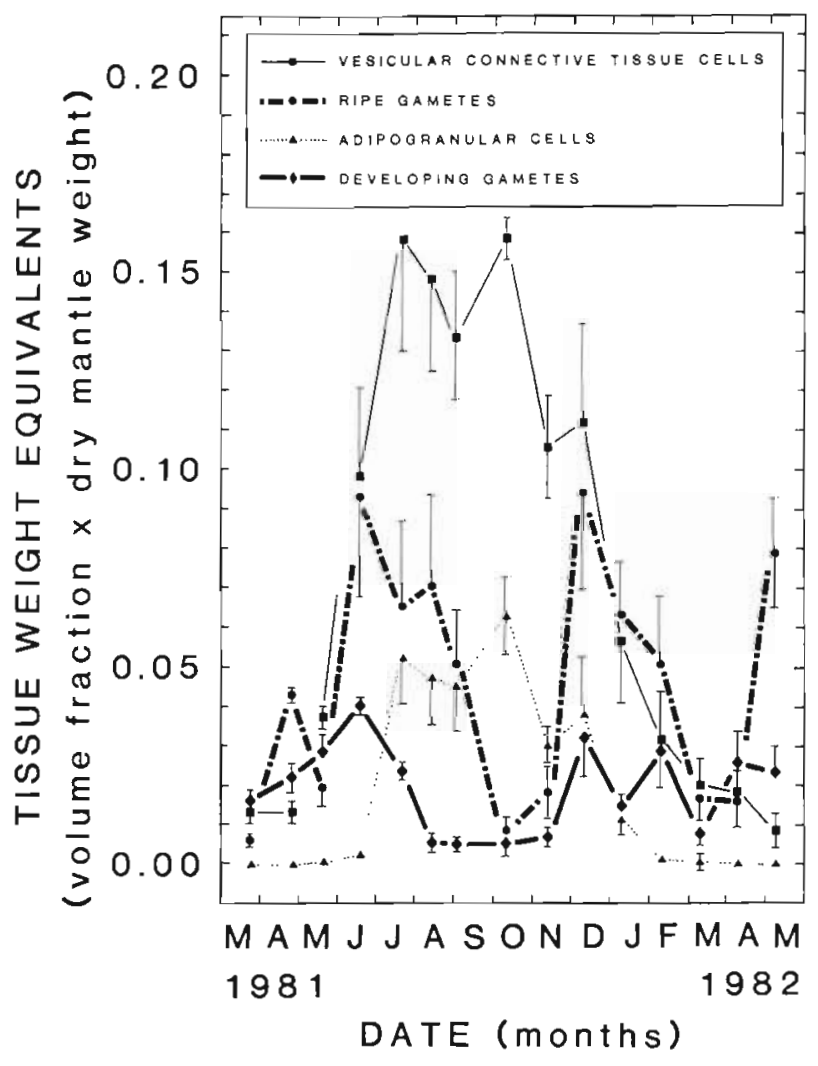

Fig. 4. Mytilus edulis. Seasonal weight equivalents (mean \pm $1 \mathrm{SE}$ ) of mantle tissue components within $50 \mathrm{~mm}$ shell-length mussels. Only standard errors greater than 0.002 are indicated

Whereas each main period of spawning corresponded with a sharp decline in total tissue dry weight $(0.35$ to $0.45 \mathrm{~g})$, both periods of gamete development were characterized by rapid body growth $(0.22$ to $0.64 \mathrm{~g}$ ) (Fig. 2 and 4). These fluctuations in weight did not derive solely from the mantle, however, but also from the digestive gland and remainder tissue divisions, when changes in each of these components were often synchronized (Fig. 2). The resultant pattern describes 2 main weight maxima, of which the peak in spring was slightly higher than that in late autumn.

\section{Elemental/biochemical composition and caloric content}

The percentage contributions of organic carbon and nitrogen, together with total inorganics, towards dry flesh weight are shown in Fig. 5. Whereas the nitrogen fraction of each tissue division increased from a minimum ( 5 to $8 \%$ ) in summer to a maximum ( 9 to $11 \%$ ) in spring, carbon content (range 40 to $47 \%$ ) followed the reverse profile, demonstrating a clear



Fig. 5. Mytilus edulis. Seasonal percentage contributions (mean \pm range; $n=3$ ) of organic carbon, organic nitrogen and total inorganics towards the dry tissue weight of $50 \mathrm{~mm}$ shell-length mussels. Symbols as in Fig. 2. Only ranges greater than $0.2 \%$ are indicated

inverse relationship between these two organic components $(r=-0.95, P<0.01)$.

The inorganic content of total dry tissues exhibited a summer minimum of 10 to $11 \%$ alternating with winter/early spring maxima of 18 to $21 \%$. This profile was similar to that for organic nitrogen $(r=0.91$, $P<0.02$ ).

Proportional fluctuations alone are of limited value, for they may result from reciprocal changes in other components (Dare and Edwards, 1975; Gabbott, 1976). Mean carbohydrate, protein and lipid contents (mg) have thus been quantified (Fig. 6) by combining their proportions (Table 2), estimated from elemental compositions (Fig. 5), with ash-free dry weight data. Mean ash contents (mg) for each tissue division (Fig. 6) were computed using percentage values that had been determined directly (Fig. 5).

The changing abundance of each biochemical component paralleled the overall annual cycle of dry weight (Fig. 2), which derived predominantly from the storage and utilization of carbohydrate. Indeed, between March 1981 and March 1982, over a period 




Fig. 6. Mytilus edulis. Seasonal changes in weight of substrates and ash within tissues of $50 \mathrm{~mm}$ shell-length mussels. Symbols as in Fig. 2. Ranges indicated, for total tissues only, illustrate the effect of $\pm 2 \%$ variation in water content: this variation does not affect protein estimates

that included both main periods of spawning, about $58 \%$ of the spring/early summer increase (up to July $1981=502 \mathrm{mg}$ ) in dry weight and $46 \%$ of the subsequent loss was attributable to changing levels of this substrate. In terms of energy units, however, the proportional decline in carbohydrate was slightly less $(42 \%)$ and the roles of both protein and lipid more significant. Clearly, glycogen, which comprises 95 to
$97 \%$ of all carbohydrates in Mytilus edulis (Gabbott and Bayne, 1973), together with protein, served as the main energy reserves, being accumulated primarily within the vesicular and adipogranular cells (Fig. 4) of the mantle (Fig. 6).

Non-mantle tissues also contributed to metabolic demands, for the digestive gland and remainder each supplied 28 to $30 \%$ of energy losses between July 1981 and March 1982. Whereas glycogen and protein contributed comparable shares to all energy furnished by the remainder tissue fraction, $55 \%$ of that supplied from the digestive gland derived from lipids, relative to only 17 and $28 \%$ from glycogen and protein, respectively. These findings emphasize the predominant role of the digestive gland in lipid storage by mussels from Whitsand Bay, as found among Mytilus edulis from Norfolk (England; Thompson, 1972). The accumulation of lipids $(70 \mathrm{mg})$ was less than for glycogen $(293 \mathrm{mg})$ and protein $(87 \mathrm{mg})$, but the rate of utilization of this substrate between July and October 1981 was noticeably faster (Fig. 6). As suggested by Zandee et al. (1980a), fatty acids may thus constitute the main source of energy production over summer months.

The balance between tissue components, expressed in terms of both carbohydrate-to-protein and carbonto-nitrogen $(\mathrm{C}: \mathrm{N})$ ratios, together with energy content, is shown in Fig. 7. These ratios are useful biochemical indices (Ansell and Sividas, 1973; Mann, 1978), providing a measure of total organics in relation to protein content and thus, by inference, a measure of nonprotein organic material available for use as respiratory substrates. Whereas elevated $\mathrm{C}: \mathrm{N}$ ratios represent the general accumulation of carbon/energy-rich substrates from early spring to mid-summer, coincident carbohydrate-to-protein ratios, which were especially

Table 2. Mytilus edulis. Seasonal percentage contributions of carbohydrate (K), protein (P) and lipid (L) towards organic dry weight of tissues sampled from $50 \mathrm{~mm}$ shell-length mussels

\begin{tabular}{|c|c|c|c|c|c|c|}
\hline \multirow[t]{2}{*}{ Date } & \multicolumn{3}{|c|}{ Total soft tissues } & \multicolumn{3}{|c|}{ Remainder } \\
\hline & K & $\mathrm{P}$ & L & $\mathrm{K}$ & $\mathrm{P}$ & $\mathrm{L}$ \\
\hline 25 Nov 1980 & 29.7 & 54.7 & 9.6 & - & - & - \\
\hline $16 \mathrm{Dec}$ & 15.3 & 67.4 & 11.3 & - & - & - \\
\hline $10 \operatorname{Mar} 1981$ & 11.1 & 75.9 & 7.0 & 4.8 & 81.2 & 8.0 \\
\hline $20 \mathrm{Jul}$ & 39.1 & 43.6 & 11.3 & 33.3 & 54.5 & 6.2 \\
\hline 12 Oct & 36.8 & 48.3 & 8.8 & 34.0 & 54.9 & 5.1 \\
\hline \multirow[t]{3}{*}{29 Маг 1982} & 10.5 & 72.0 & 11.6 & 5.6 & 75.7 & 12.7 \\
\hline & \multicolumn{3}{|c|}{ Mantle } & \multicolumn{3}{|c|}{ Digestive gland } \\
\hline & $\mathrm{K}$ & $\mathrm{P}$ & $\mathrm{L}$ & $\mathrm{K}$ & $P$ & $\mathrm{~L}$ \\
\hline 10 Mar 1981 & 13.0 & 72.4 & 8.6 & 27.8 & 64.2 & 2.0 \\
\hline $20 \mathrm{Jul}$ & 52.9 & 35.1 & 6.0 & 25.3 & 36.8 & 31.8 \\
\hline $12 \mathrm{Oct}$ & 51.8 & 36.1 & 6.1 & 32.8 & 45.1 & 16.2 \\
\hline 29 Mar 1982 & 18.4 & 66.3 & 9.3 & 22.0 & 62.6 & 9.4 \\
\hline
\end{tabular}




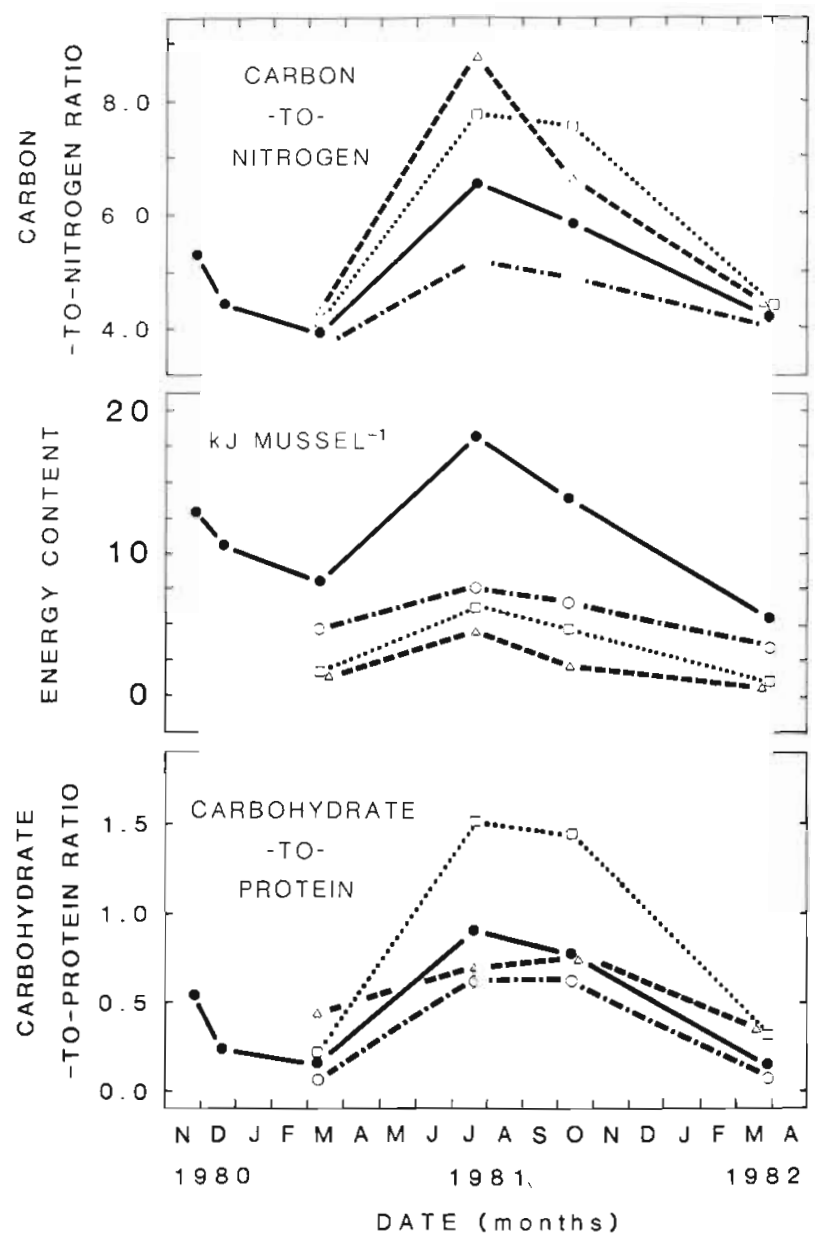

Fig. 7. Mytilus edulis. Seasonal changes in organic carbon-tonitrogen (C:N) ratio, carbohydrate-to-protein ratio and energy content within tissues of $50 \mathrm{~mm}$ shell-length mussels. Symbols as in Fig. 2

high for germinal tissue (1.6 to 1.8 ), reflect the predominant storage of lipid and glycogen within the digestive gland and mantle. Minimum values were recorded over winter months, resulting in annual (March 1981-March 1982) means ( $\pm 2 \mathrm{SE}, n=4$ ) for the total soft tissues of $0.49 \pm 0.40,5.12 \pm 1.30$ and $22.17 \pm$ 0.98 for carbohydrate-to-protein ratios, $\mathrm{C}: \mathrm{N}$ ratios and energy content ( $\mathrm{kJ} \mathrm{g}^{-1}$ dry organic tissue weight), respectively.

\section{Physiological rates and absorption efficiencies}

Analysis of covariance showed that the coefficients ( $b$ values) from regressions of oxygen consumption $\left(\dot{N}_{\mathrm{O}_{2}}\right)$, net ammonia nitrogen loss $\dot{N}_{\mathrm{NH}_{4}}$ and ingestion rate (IR) against dry tissue weight of mussels from Whitsand Bay, did not differ significantly $(P>0.05)$ between March and August 1981. These results are consistent with previous indications that the relations

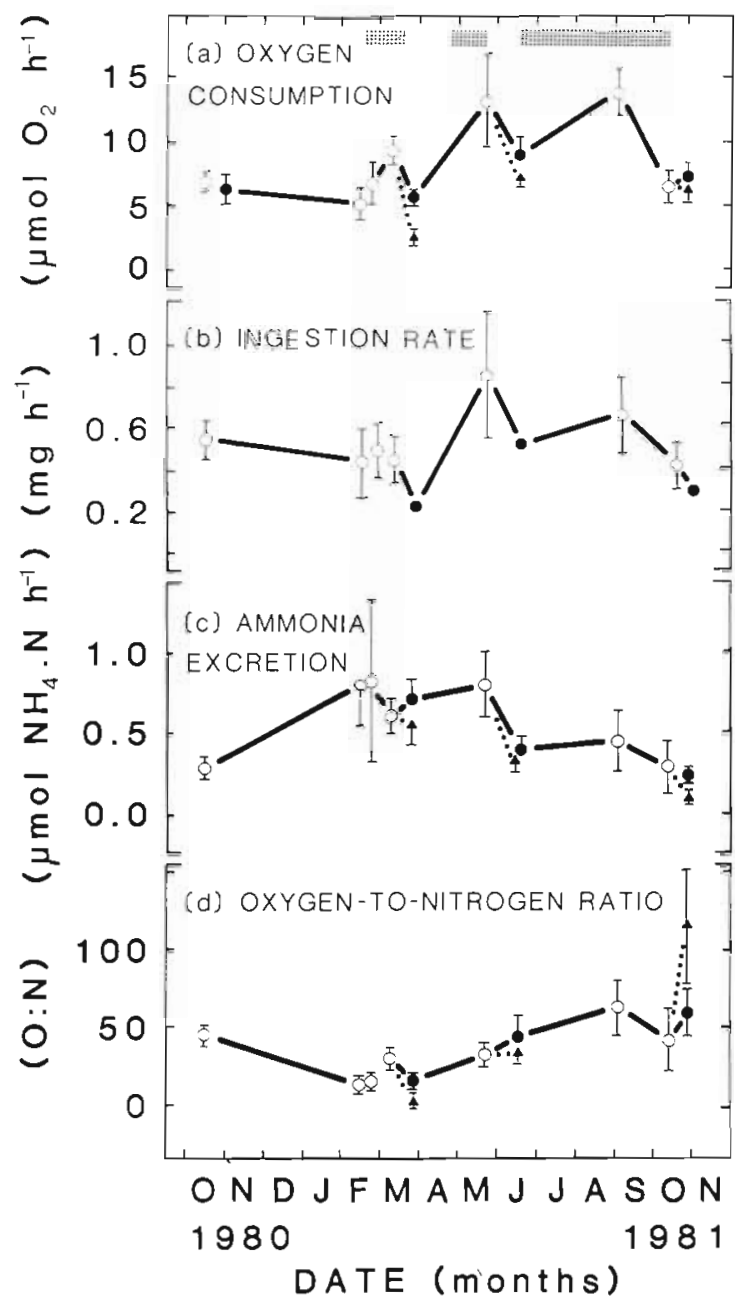

Fig. 8. Mytilus edulis. Seasonal changes (mean $\pm 2 \mathrm{SE}$ ) in the physiology of $0.65 \mathrm{~g}$ dry tissue-weight mussels either fed (circles) or starved (triangles) throughout $<1$ wk (open symbols) and 5 to $6 \mathrm{wk}$ (closed symbols, illustrated $2 \mathrm{wk}$ after mussel collection) periods of acclimation. Shaded horizontal bars delineate periods of known spawning (Fig. 4)

between physiological rates and body size in bivalve molluscs do not vary with season. Common coefficients were thus determined $\left(\dot{N}_{\mathrm{O}_{2}}, \quad b=0.478 ; \dot{N}_{\mathrm{NH}_{4}}, b=\right.$ 0.720 ; IR, $b=0.452$ ), and used to transform physiological rates measured for $45-57 \mathrm{~mm}$ shell length mussels (Table 3) to those for a standard individual of $0.65 \mathrm{~g}$ total dry tissue weight (Fig. 8), representing the approximate mid-point of annual fluctuations in body size (Fig. 2).

In Fig. 9 are plotted seasonal measurements relating oxygen consumption $\left(\dot{N}_{\mathrm{O}_{2}}\right.$ ) and ingestion rate (IR). This relation can be described by the equation:

$$
\dot{N}_{\mathrm{O}_{2}}=3.88 e^{(1.4 \mathrm{IR})}(n=10 ; r=0.78 ; p<0.01) \text {. }
$$

The $95 \%$ confidence limits indicate the extent to which the ratio between these two variables may be modified in response to changing metabolic require- 
ments. In addition, the intercept on the ordinate ( $\left.3.88 \mu \mathrm{mol} \mathrm{O} \mathrm{O}_{2} \mathrm{~h}^{-1}\right)$ is assumed to approximate the 'standard' rate characteristic of quiescent animals (Bayne et al., 1973).

Mytilus edulis is similar to many other marine invertebrates in its ability to acclimate to temperatures between 5 and $20^{\circ} \mathrm{C}$ (Widdows and Bayne, 1971; Widdows, 1976; Newell, 1979). Accordingly, seasonal variations in both $\dot{\mathrm{N}}_{\mathrm{O}_{2}}$ and IR (Fig. 8) cannot have been in

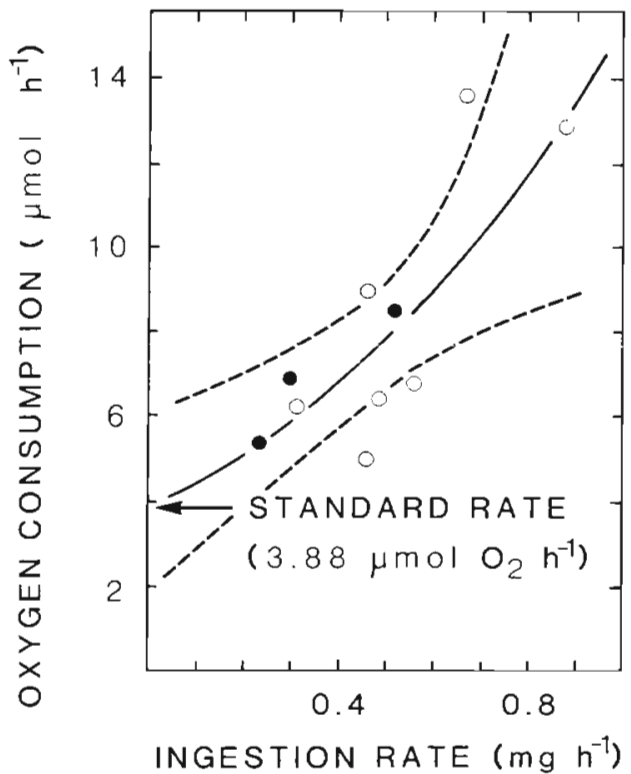

Fig. 9. Mytilus edulis. Relation between seasonal variations in rates of oxygen uptake and ingestion of Phaeodactylum tricornutum by $0.65 \mathrm{~g}$ dry tissue weight mussels fed throughout $<1 \mathrm{wk}$ (open circles) and 5 to $6 \mathrm{wk}$ (closed circles) periods of acclimation between October 1980 and October 1981 (Fig. 8). Fitted curve is described in text; dashed lines: $95 \%$ confidence limits response to changing seawater temperatures (Fig. 1) alone. Rather, these fluctuations appear to correlate with the reproductive cycle and fluxing of body reserves, for individual peaks of activity between February and October 1981 were in each case coincident with known periods of spawning and/or an increasing abundance of storage cells (Fig. 3 and 4). In addition, the overall increase in $\dot{N}_{\mathrm{O}_{2}}$ from March 1981, and subsequent decline between September and October 1981, corresponded with the changing abundance (weight equivalents) of ripe gametes (Fig. 4 and 8). Not unexpectedly, in view of the small number of directly comparable values $(n=5)$, these associations were not statistically $(P>0.05)$ significant. Such relations, however, concerning metabolic rate and the reproductive/ storage cycle, are consistent with previous findings for $M$. edulis and other lamellibranchs (Bayne, 1976; Vahl, 1978; Newell and Bayne, 1980).

As for both $\dot{N}_{\mathrm{O}_{2}}$ and IR, minimum rates of ammonia loss occurred during a period of germinal quiescence in early winter (Fig. 3 and 8). The subsequent rise to maximum values, however, paralleled both the decline in mantle reserves and initiation of gametogenesis between October 1980 and February 1981, rather than occurring over early summer and autumn when maximum rates of both oxygen uptake and ingestion rate were apparent. Consequently, the ratio of oxygen consumed to ammonia nitrogen excreted (O:N ratio) showed substantial seasonal variation (Fig. 8), such that the proportional contribution of protein to total catabolic substrates ( $W_{\mathrm{p}}$; Table 3 ) was considerably higher in March (33 to $67 \%$ ) than in June or October (6 to $19 \%$ ).

During 1981 the mean efficiencies with which mussels, fed during acclimation, absorbed organic matter

Table 3. Mytilus edulis. Physiological responses of 45 to $57 \mathrm{~mm}$ shell-length mussels either fed or starved throughout 5 to 6 wk periods of acclimation in March, June and October 1981. Whereas the mean $\pm 2 \mathrm{SE}$ is given for ${N_{\mathrm{O}^{\prime}}}_{N_{\mathrm{NH}}}$ and O:N ratios, values for the rate of ingestion of Phaeodactylum tricornutum are 6 hourly means for 145 to 150 mussels. Nitrogen quotients (NQ) are presented for comparison, and the relative contribution of the mass of protein $\left(W_{p}\right)$ to the total catabolic substrates is calculated for $R Q$ values of $0.95 / 0.85$ (cf. Gnaiger, 1983)

\begin{tabular}{|c|c|c|c|c|c|c|}
\hline \multirow[t]{2}{*}{ Response } & \multicolumn{2}{|c|}{ March } & \multicolumn{2}{|c|}{ June } & \multicolumn{2}{|c|}{ October } \\
\hline & Fed & Starved & Fed & Starved & Fed & Starved \\
\hline $\begin{array}{l}\text { Oxygen consumption } \\
\left(\mu \mathrm{mol} \mathrm{O}_{2} \mathrm{~h}^{-1}\right)\end{array}$ & $4.01 \pm 0.89$ & $1.78 \pm 0.45$ & $8.03 \pm 1.34$ & $6.25 \pm 0.89$ & $7.58 \pm 1.34$ & $6.69 \pm 1.34$ \\
\hline $\begin{array}{l}\text { Excretion rate } \\
\left(\mu \mathrm{mol} \mathrm{NH} \mathrm{h}_{4} \mathrm{~h}^{-1}\right)\end{array}$ & $0.39 \pm 0.04$ & $0.29 \pm 0.04$ & $0.45 \pm 0.05$ & $0.34 \pm 0.03$ & $0.23 \pm 0.02$ & $0.12 \pm 0.02$ \\
\hline $\begin{array}{l}\text { Ingestion rate } \\
\left(\mathrm{mg} \mathrm{h}^{-1}\right)\end{array}$ & 0.17 & - & 0.53 & - & 0.31 & - \\
\hline $\begin{array}{l}\mathrm{O}: \mathrm{N} \text { ratio } \\
\text { (atomic equivalents) }\end{array}$ & $21.5 \pm 5.6$ & $11.0 \pm 4.1$ & $36.6 \pm 11.0$ & $35.8 \pm 8.7$ & $65.6 \pm 16.3$ & $107.7 \pm 8.4$ \\
\hline $\begin{array}{l}\text { Nitrogen quotient } \\
(N Q=2 / O: N)\end{array}$ & 0.093 & 0.182 & 0.055 & 0.056 & 0.030 & 0.019 \\
\hline$W_{p}$ & $0.33 / 0.44$ & $0.67 /-$ & $0.19 / 0.26$ & $0.19 / 0.25$ & $0.10 / 0.14$ & $0.06 / 0.08$ \\
\hline
\end{tabular}


as a whole were slightly lower in winter (0.38) than in summer and autumn (0.52 to 0.55) (Fig. 10). A supplementary experiment at $9^{\circ} \mathrm{C}$ in February 1982 confirmed the trend towards lower winter absorption (0.43). Absorption efficiencies may be very high 10.70 to 0.80 ) upon administering mussels cultured algal cells, including Phaeodactylum tricornutum (Kiorboe et al., 1981), at ambient concentrations comparable to

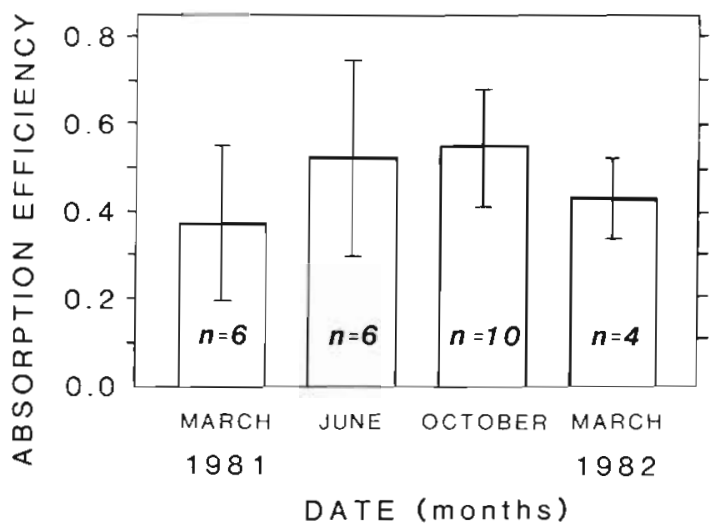

Fig. 10. Mytilus edulis. Seasonal absorption efficiencies (Conover, 1966) (mean $\pm 2 \mathrm{SE}$ ) of Phaeodactylum tricornutum by 45 to $57 \mathrm{~mm}$ shell-length mussels fed throughout 5 to $6 \mathrm{wk}$ periods of acclimation: $n$ : number of replicate determinations undertaken, each for a group of 10 mussels

those maintained during this study. Efficiencies reported here, however, generally fell within the range 0.30 to 0.70 , more typical of suspension feeders ingesting natural seston (Griffiths, 1980b; Bayne and Newell. 1983).

\section{Scope for growth, conversion efficiencies and maintenance requirements}

Computations of scope for growth in both fed and starved 45 to $57 \mathrm{~mm}$ shell-length mussels acclimated in March, June and October 1981, are shown in Table 4. Because each physiological value represents the mean for separate mussel groups, direct estimation of the variance associated with each computation of scope for growth is not possible. Bayne and Widdows (1978), however, have used Monte Carlo simulation to calculate a variance:mean ratio of 0.55 for similar computations

Although not depicting the full seasonal cycle of scope for growth, the results indicate that whereas negative values determined in March $\left(-0.76 \mathrm{~J} \mathrm{~h}^{-1}\right)$ and October $\left(-0.40 \mathrm{~J} \mathrm{~h}^{-1}\right)$ related to general declines in condition, the highest measured value in June $\left(+1.23 \mathrm{~J} \mathrm{~h}^{-1}\right)$ corresponded with the period of most dramatic tissue growth (Fig. 2). These findings, and also those of Dame (1972), Bayne et al., (1979) and Bayne and Worrall (1980), confirm that careful analysis of energy budgeting may provide reasonable predictions of growth itself.

Scope for growth, expressed as a proportion of the absorbed ration, represents net growth efficiency $\left(K_{2}\right)$ (Ivlev, 1961). This efficiency reached a maximum of 0.25 during summer (Table 4), reflecting the rapid accumulation of body reserves evident at that time. Similar seasonal variations occur in Mytilus edulis feeding upon natural particulates when, as suggested here, net conversion efficiency is an increasing function of absorbed ration (Bayne and Widdows, 1978). In addition, estimates of the 'gross efficiency' with which ration was utilized to offset net energy deficits (ensuing from maintenance metabolism, together with any somatic growth and/or reproduction) were derived by computing each increment in scope for growth as a fraction of the associated ration absorbed (Table 4). Clearly, such overall efficiency was considerably reduced in winter $(0.12)$ relative to summer $(0.83)$ and autumn (0.86).

To investigate the potential influence of fluctuating metabolic demands upon changing net growth efficiencies, both absorbed and ingested instantaneous 'maintenance requirements' were estimated by equating ration-specific increments of scope for growth in relation to known rates of oxidative metabolism and ammonia excretion (e.g. Kleiber, 1961, p. 279) (Table 4). For example, comparison of the scopes for growth of mussels either fed or starved in March 1981 shows that:

(a) $(0.90-0.76)=0.14 \mathrm{~J}$ of body energy were saved by $3.08 \mathrm{~J}$ of ingested energy; and thus that

(b) the ingested ration necessary to sustain a zero scope for growth (i.e. the maintenance ration) would have been $(3.08 \times 0.90) / 0.14=19.80 \mathrm{~J} \mathrm{~h}^{-1}$.

These computations assume that (a) relations between components of energy expenditure and either absorption or ingestion rates are linear throughout the range of fed and starved conditions reported here, and (b) the same seasonal relations govern any changes required to reach a short-term steady state. Results indicate that, relative to summer $\left(3.51 \mathrm{~J} \mathrm{~h}^{-1}\right)$ and autumn (3.56 $\mathrm{J} \mathrm{h}^{-1}$ ), an increase in the absorbed maintenance requirement for late March (7.52 $\mathrm{J} \mathrm{h}^{-1}$ ) contributed towards reduced net growth efficiency at that time. This increase in absorbed maintenance requirement derived in part from an impaired gross efficiency, quite apart from the concurrent energy demands of vitellogenesis (cf. Thompson and Bayne, 1974) (Fig. 3 and 4). In view of the reduced absorption efficiency evident during March, the winter increase in ingested maintenance requirement was more pro- 
Table 4. Mytilus edulis. Computation of scope for growth, conversion efficiencies and maintenance requirements of 45 to $57 \mathrm{~mm}$ shell-length mussels either fed or starved throughout 5 to $6 \mathrm{wk}$ periods of acclimation in March, June and October 1981

\begin{tabular}{|c|c|c|c|c|c|c|c|c|c|c|}
\hline \multirow{2}{*}{$\begin{array}{l}\text { Date and } \\
\text { nutritional } \\
\text { status }\end{array}$} & \multirow{2}{*}{$\begin{array}{l}\text { Ingested } \\
\text { ration } \\
\left(\mathrm{J} \mathrm{h}^{-1}\right)\end{array}$} & \multirow{2}{*}{$\begin{array}{l}\text { Absorp- } \\
\text { tion } \\
\text { efficiency } \\
(\%)\end{array}$} & \multirow{2}{*}{$\begin{array}{l}\text { Absorbed } \\
\text { ration } \\
\left(\mathrm{J} \mathrm{h}^{-1}\right)\end{array}$} & \multirow{2}{*}{$\begin{array}{c}\text { Oxygen } \\
\text { consump- } \\
\text { tion } \\
\left(\mathrm{J} \mathrm{h}^{-1}\right)\end{array}$} & \multirow{2}{*}{$\begin{array}{c}\text { Ammonia- } \\
\text { Nexcre- } \\
\text { tion } \\
\left(\mathrm{J} \mathrm{h}^{-1}\right)\end{array}$} & \multirow{2}{*}{$\begin{array}{l}\text { Scope } \\
\text { for } \\
\text { growth } \\
\left(\mathrm{J} \mathrm{h}^{-1}\right)\end{array}$} & \multirow{2}{*}{$\begin{array}{c}\text { Net } \\
\text { growth } \\
\text { efficiency } \\
(\%)\end{array}$} & \multirow{2}{*}{$\begin{array}{c}\text { 'Gross } \\
\text { efficiency' } \\
(\%)\end{array}$} & \multicolumn{2}{|c|}{$\begin{array}{l}\text { Maintenance } \\
\text { requirements }\end{array}$} \\
\hline & & & & & & & & & $\begin{array}{l}\text { Ingested } \\
\qquad\left(\mathrm{J} \mathrm{h}^{-1}\right)\end{array}$ & $\begin{array}{c}\text { Absorbed } \\
\left(\mathrm{J} \mathrm{h}^{-1}\right)\end{array}$ \\
\hline \multicolumn{11}{|l|}{ MARCH } \\
\hline Fed & 3.08 & 0.38 & 1.17 & 1.80 & 0.13 & -0.76 & -0.65 & 0.12 & \multirow{2}{*}{19.80} & \multirow{2}{*}{7.52} \\
\hline Starved & - & - & - & 0.80 & 0.10 & -0.90 & - & - & & \\
\hline \multicolumn{11}{|l|}{ JUNE } \\
\hline Fed & 9.59 & 0.52 & 4.99 & 3.61 & 0.15 & +1.23 & +0.25 & 0.83 & \multirow{2}{*}{6.75} & \multirow{2}{*}{3.51} \\
\hline Starved & - & - & - & 2.81 & 0.12 & -2.93 & - & - & & \\
\hline \multicolumn{11}{|l|}{ OCTOBER } \\
\hline Fed & 5.61 & 0.55 & 3.09 & 3.41 & 0.08 & -0.40 & -0.13 & 0.86 & \multirow{2}{*}{6.46} & \multirow{2}{*}{3.56} \\
\hline Starved & - & - & - & 3.01 & 0.04 & -3.05 & - & - & & \\
\hline
\end{tabular}

nounced than that for the absorbed inaintenance requirement (Table 4). When expressed in terms of algal mass, this absorbed requirement varied from $2.8 \%$ of dry tissue weight per day in March to 1.0 and $0.6 \%$ in June and October, respectively. Such values, determined by the differencing described, correspond with the lower end of the range between 0.2 and about $6 \%$ derived for Mytilus edulis using growth efficiency ( $K$-line) analyses (Thompson and Bayne, 1974; Winter and Langton, 1976; Bayne and Widdows, 1978; Widdows, 1978b; Widdows et al., 1979).

\section{DISCUSSION}

In addition to various physiological measurements, tissue-specific biochemical contents within mussels from Whitsand Bay, computed from measured elemental compositions, have indicated an overall seasonal pattern concerning the storage and ultimate utilization of energy reserves which is basically consistent with findings for Mytilus subspecies elsewhere (see references cited in Introduction). This cycle was intimately linked with those of growth and reproduction. Similar associations, both in Mytilus edulis and other lamellibranch species, have been reviewed by Giese (1969), Gabbott (1975, 1976, 1983), Sastry (1975) and Bayne (1976).

A considerable body of evidence (reviewed by Giese, 1959; Kinne, 1970; Sastry, 1975) suggests that threshold temperatures and/or rates of change in temperature (Chipperfield, 1953; Bayne, 1975) are primary factors influencing bivalve reproductive cycles. Such an influence was not obvious upon Whitsand mussels, however, for 2 main periods of spawning in summer 1981 and early spring 1982 were evident at very different surface water temperature ranges of 14 increasing to $17^{\circ} \mathrm{C}$ and 11 decreasing to $9^{\circ} \mathrm{C}$, respectively (Fig. 1 and 4). Rather, the observation that each major period of gametogenesis (March/June and November/December 1981) coincided with weight increases of both the digestive gland and other tissues infers that food availability may be of relatively greater importance to gamete maturation within this population. It is well known that in shallow waters of the western English Channel there is both a spring and an autumn peak in diatom production (Maddock et al., 1981). Further, the fact that the spring peak is generally higher than in autumn (Boalch et al., 1978) may reflect the relative increases of dry tissue weight at those times (Fig. 2).

Mytilus edulis, together with Pecten maximus and Macoma balthica, often behave in a 'conservative' manner, utilizing large nutrient reserves to buffer gametogenesis from environmental changes (Bayne, 1976; Waldock and Holland, 1979). Indeed, results presented here suggest that, especially in autumn, reserves from germinal and probably somatic tissues made a partial contribution, direct or otherwise, towards meeting the demands associated with gamete development (Fig. 4 and 6). Overall, however, gametogenesis was mostly 'opportunistic', being sustained predominantly by the input of nutrients from feeding alone. Such behaviour has previously been described for a variety of bivalves (Bayne, 1976; Griffiths, 1977; Thompson, 1977), including $M$. edulis from Newfoundland (Thompson, 1984). Clearly, M. edulis, in common with Chlamys varia (Shafee, 1981), may also utilize strategies intermediate between these 2 extremes. These observations support the growing realization (e.g. Newell et al., 1982; Gabbott, 1983; Thompson, 1984) that, for a given species living in a variety of habitats, the varying interactions of temperature and food availability, set within a seasonal context, may condition quite different adaptations con- 
cerning the timing of gametogenesis and its relation to both the storage and utilization of nutrient reserves.

Results of this study are consistent with previous research suggesting that seasonal changes in oxygen demand correlate with events in the reproductive cycle of Mytilus edulis (Bruce, 1926; Krüger, 1960; Bayne, 1973; Gabbott and Bayne, 1973; De Vooys, 1976; Bayne and Widdows, 1978; Widdows, 1978a). Oxidative metabolism also varied in response to changing food availability, although the responses appear seasonally dependent. When, in March 1981, O:N ratios indicated a marked metabolic dependence upon protein substrates, the rate of oxygen uptake by starved $M$. edulis $\left(2.23 \pm 0.18\right.$ [2 SE] $\left.\mu \mathrm{mol} \mathrm{O}_{2} \mathrm{~h}^{-1}\right)$ showed a significant decline to levels below the 'standard rate' characteristic of quiescent animals. During both June and October 1981, however, which represented periods of germinal activity and quiescence, respectively, rates of oxygen consumption remained relatively unchanged following even $5 \mathrm{wk}$ of starvation. Such stability suggests that, when carbon-rich reserves are available in sufficient quantity, their controlled hydrolysis may operate to sustain both reproductive and somatic requirements independant of environmental nutrient availability. The low gross efficiency computed for March, relative to June and October, must partially reflect a reduced subsidy to ingested nutrients, from pre-stored reserves, by mussels starved at that time. These findings therefore high-light the need for careful appraisal of conversion efficiencies, as discussed by Calow (1977), for adjustments may partially derive through modification in the partitioning of energy between production and maintenance metabolism.

The standard metabolic rate derived for Whitsand mussels of $0.65 \mathrm{~g}$ dry tissue weight comprises the 'physiological' costs of digestion and assimilation (Warren and Davis, 1967), together with a 'basal' component (cf. Bayne et al., 1976a; Bayne and Newell, 1983). In the context of results described here, this standard rate ( $3.88 \mu \mathrm{mol} \mathrm{O} \mathrm{O}_{2} \mathrm{~h}^{-1}$ ) is interpreted as representing the seasonal minimum of oxidative metabolism among quiescent individuals. Coincident with starvation and the associated reduction of physiological costs, oxygen uptake will eventually decline to the basal level. However, in view of the regulatory mechanism discussed above, only the reduced rate of oxygen consumption by mussels starved during March approximated such a minimum. Subtraction of this rate $\left(2.23 \mu \mathrm{mol} \mathrm{O} \mathrm{O}_{2} \mathrm{~h}^{-1}\right.$ per $0.65 \mathrm{~g}$ dry tissue weight individual) from that estimated for standard metabolism indicates that the physiological cost of digestion and assimilation among Mytilus edulis was at least $1.65 \mu \mathrm{mol} \mathrm{O}_{2} \mathrm{~h}^{-1}$ or 0.74 $\mathrm{J} \mathrm{h}^{-1}$. This represents a physiological cost of about $18 \%$ of the ration ingested $\left(4.21 \mathrm{~J} \mathrm{~h}^{-1}\right)$, compared with previous estimates of $4 \%$ in Mytilus edulis (Bayne and Scullard, 1977b), $6 \%$ in $M$. californianus (Bayne et al., $1976 \mathrm{a}$ ), 18 to $30 \%$ in $M$. chilensis (Navarro and Winter 1982 ) and values from 5 to $40 \%$ in various fish (Warren and Davis, 1967; Pierce and Wissing, 1974; Vahl and Davenport, 1979; Soofiani and Hawkins, 1982). During winter, when nutrient reserves are depleted and mussels mostly reliant on protein substrates, such a cost clearly contributes to both the low gross efficiencies and high maintenance requirements documented here.

Whereas the basal rate of oxygen consumption $\left(\mathrm{J} \mathrm{h}^{-1}\right)$ by March-acclimated mussels represented only $24 \%$ of the ingested ration, supplementary costs deriving from feeding and associated activities added a further $\left(5.35-3.88=1.47 \mu \mathrm{mol} \mathrm{O} \mathrm{O}_{2} \mathrm{~h}^{-1}\right.$ or $\left.0.66 \mathrm{~J} \mathrm{~h}^{-1}\right)$ $38 \%$ to the standard metabolic demand. An expense of this magnitude constitutes sound energetic grounds for the temporally variable rates of filtration by Mytilus edulis which, apparent under environmentally invariant conditions (Jørgensen, 1949; Theede, 1963; Winter, 1969, 1973; Schulte, 1975; Bayne et al., 1977; Davenport and Woolmington, 1982), probably relate to rhythms of digestion and excretion (Hawkins et al., 1983).

The integration of physiological processes into general condition indices can provide fundamental measures of an animal's overall performance in response to changing environmental parameters. In particular, scope for growth, as an index of the energy available for production, has descriptive validity over a wide range of environmental conditions, and has been computed extensively in studies upon bivalve molluscs (reviewed by Bayne et al., 1976b; Newell, 1979; Bayne and Newell, 1983). During the present study, values of this index derived after periods of laboratory acclimation, throughout which Mytilus edulis were administered algal monoculture alone, remained consistent with seasonal changes in the dry tissue weight of mussels within their natural environment. Clearly, the absence of resuspended bottom material (detrital, bacterial and/or inorganic), which has been found to stimulate rates of both absorption and growth (Winter, 1976, 1978; Kiørboe et al., 1980, 1981), does not effect the bioenergetic steady-state evident among Whitsand mussels. These findings conform with those of Riisgard and Randlov (1981), who reported that a 'restricted' diet of Phaeodactylum tricornutum enables $M$. edulis from Denmark to grow at rates comparable with those found in nature.

Given that experimental nutrient availability and salinity were standardized, it is significant that scope for growth remained negative among Mytilus edulis fed throughout 5 to $6 \mathrm{wk}$ of acclimation in both March and October, when rates of absorption were well below those recorded in June (Table 4). This finding suggests 
an endogenous (e.g. Naylor, 1976; Saunders, 1977) influence concerning seasonal variation in rates of feeding and energy (or nutrient) utilization. Many bivalves (Griffiths, 1980a; Palmer and Williams, 1980; Navarro and Winter, 1982; Gerdes, 1983; Seiderer et al., 1984), including $M$. edulis (Thompson and Bayne, 1972, 1974; Winter, 1973; Foster-Smith, 1975a, b; Widdows, 1978a), display some ability to regulate feeding in response to short-term changes in food availability. It is also widely recognized that endogenous factors (nutrient reserves, hormonal cycle, etc.) influence the initiation and duration of seasonal activities such as gametogenesis. It seems likely, then, that endogenous variables may also regulate the long-term balance between acquisition and utilization of resources among bivalves. In this context it is of interest that seasonal alterations of the kinetic characteristics of several regulatory enzymes have been linked to observed or indicated changes of metabolic flux in both $M$. edulis (Livingstone, 1975, 1981; Gabbott et al., 1979; Livingstone and Clarke, 1983) and $M$. galloprovincialis (Goromosova and Tamozhynyaya, 1980).

The observation that Mytilus edulis may not maximize its net energy balance in the short-term, at least during certain times of the year, lends credence to the 'general' form of Doyle's (1979) energy-maximization hypothesis, which predicts that feeding behaviour may be optimal only in 'some time-averaged sense'. Endogenous regulation concerning seasonal changes in feeding and energy expenditure may be especially adaptive among sedentary species that experience both short-term fluctuations and pronounced annual cycles of food availability. By this means, for example, wasteful metabolic (enzyme) adjustment to short-term fluctuations in either the quality or quantity of nutrient supply might be avoided. Negative scope for growth, when recorded for $M$. edulis in its natural environment, occurs concurrently with minima in the organic content of total seston, and derives largely from decreases in absorption efficiency and/or ingestion rate (Bayne and Widdows, 1978; Bayne et al., 1979; Widdows et al., 1979, 1981a). The reduced rate of absorption among Whitsand mussels fed throughout acclimation during March, at least, and which was sustained despite coincident utilization of stored reserves, may thus represent a widespread time-averaged and energy saving adaptation in response to potentially high cost/benefit ratios associated with processing largely inorganic field-ambient seston. Physiological variables effecting such regulation are considered elsewhere (Hawkins and Bayne, 1984).

Acknowledgements. We thank Dr. J. Widdows and Dr. D. Livingstone for helpful discussions, Dr. K. Clarke for statistical guidance, Mr. P. Watson for technical advice, Miss M. Day for laboratory assistance and Prof. R. C. Newell for critically reviewing the manuscript. Miss G. Bitterlich undertook the direct determinations of proximate biochemical composition. A. H. gratefully acknowledges the support of a N.E. R. C. Research Studentship, and E. G. thanks the British Council for a Studentship. This work forms part of the Adaptive Processes programme of the Institute for Marine Environmental Research, a component of the U. K. Natural Environment Research Council.

\section{LITERATURE CITED}

Ansell, A. D., Sivadas, P. (1973). Some effects of temperature and starvation on the bivalve Donax vittatus (da Costa) in experimental laboratory populations. J. exp. mar. Biol. Ecol. 13: 229-262

Barber, B. J., Blake, N. J. (1981). Energy storage and utilization in relation to gametogenesis in Argopecten irradians concentricus (Say). J. exp. mar. Biol. Ecol. 52: 121-134

Bayne, B. L. (1971). Oxygen consumption by three species of lamellibranch mollusc in declining ambient oxygen tension. Comp. Biochem. Physiol. 40: 955-970

Bayne, B. L. (1973). Physiological changes in Mytilus edulis L. induced by temperature and nutritive stress. J. mar. biol. Ass. U. K. 53: 39-58

Bayne, B. L. (1975). Reproduction in bivalve molluscs under environmental stress. In: Vernberg, F. J. (ed.) Physiological ecology of estuarine organisms. University of South Carolina Press, Columbia, p. 259-277

Bayne, B. L. (1976). Aspects of reproduction in bivalve molluscs. In: Wiley, M. (ed.) Estuarine processes, Vol. 1, Uses, stresses and adaptation to the estuary. Academic Press, New York, p. 432-448

Bayne, B. L., Bayne, C. J., Carefoot, T. C., Thompson, R. J (1976a). The physiological ecology of Mytilus californianus Conrad. 1. Metabolism and energy balance. Oecologia (Berl.) 22: 211-228

Bayne, B. L., Bubel, A., Gabbott, P. A., Livingstone, D. R. Lowe, D. M., Moore, M. N. (1982). Glycogen utilization and gametogenesis in Mytilus edulis L. Mar. Biol. Lett. 3: 89-105

Bayne, B. L., Moore, M. N., Widdows, J., Livingstone, D. R., Salkeld, P. (1979). Measurements of the responses of individuals to environmental stress and pollution: studies with bivalve molluscs. Phil. Trans. R. Soc. Lond. B 286: 563-581

Bayne, B. L., Newell, R. C. (1983). Physiological energetics of marine molluscs. In: Wilbur, K. M. (ed.) The Mollusca, Vol. IV. Academic Press, New York, p. 407-515

Bayne, B. L., Scullard, C. (1977a). Rates of nitrogen excretion by species of Mytilus (Bivalvia: Mollusca). J. mar. biol. Ass. U. K. 57 : 355-369

Bayne, B. L., Scullard, C. (1977b). An apparent specific dynamic action in Mytilus edulis L. J. mar. biol. Ass. U. K. 57: $371-378$

Bayne, B. L., Thompson, R. J., Widdows, J. (1973). Some effects of temperature and food on the rate of oxygen consumption by Mytilus edulis L. In: Wieser, W. (ed.) Effects of temperature on ectothermic organisms. Springer-Verlag, Berlin, p. 181-193

Bayne, B. L., Widdows, J. (1978). The physiological ecology of two populations of Mytilus edulis L. Oecologia (Berl.) 37: $137-162$

Bayne, B. L., Widdows, J., Newell, R. I. E. (1977). Physiological measurements on estuarine bivalve molluscs in the field. In: Keegan, B. F., Ceidigh, P. O., Boaden, P. J. S. 
(ed.) Biology of benthic organisms, 11th European Symposium on Marine Biology, Galway. Pergamon Press, Oxford, p. 57-68

Bayne, B. L., Widdows, J., Thompson, R. J. (1976b). Physiological integrations. In: Bayne, B. L. (ed.) Marine mussels, International Biological Programme, Vol. 10. Cambridge University Press, Cambridge, p. 261-292

Bayne, B. L., Worrall, C. M. (1980). Growth and production of mussels (Mytilus edulis L.) from two populations. Mar. Ecol. Prog. Ser. 3; 317-328

Boalch, G. T., Harbour, D. S., Butler, E. I. (1978). Seasonal phytoplankton production in the western English Channel 1964-1974. J. mar. biol. Ass. U. K. 58: 943-953

Bruce, J. R. (1926). The respiratory exchange of the mussel (Mytilus edulis L.). Biochem. J. 20: 829-846

Calow, P. (1977). Conversion efficiencies in heterotrophic organisms. Biol. Rev. 52: 385-409

Chipperfield, P. N. J. (1953). Observations on the breeding and settlement of Mytilus edulis (L.) in British waters. J. mar. biol. Ass. U. K. 32: 449-476

Conover, R. J. (1966). Assimilation of organic matter by zooplankton. Limnol. Oceanogr. 11: 338-345

Corner, E. D. S., Cowey, C. B. (1968). Biochemical studies on the production of marine zooplankton. Biol. Rev. 43: $393-426$

Dame, R. F. (1972). The ecological energies of growth, respiration and assimilation in the intertidal American oyster Crassostrea virginica. Mar. Biol. 17: 243-250

Dare, P. J., Edwards, D. B. (1975). Seasonal changes in flesh weight and biochemical composition of mussels (Mytilus edulis L.) in the Conwy estuary in N. Wales. J. exp. mar. Biol. Ecol. 18: 89-97

Davenport, J., Woolmington, A. D. (1982). A new method of monitoring ventilatory activity in mussels and its use in a study of the ventilatory patterns of Mytilus edulis L. J. exp. mar. Biol. Ecol. 62: 55-67

De Vooys, C. G. N. (1976). The influence of temperature and time of the year on the oxygen uptake of the sea mussel Mytilus edulis. Mar. Biol. 36: 25-30

Doyle, R. W. (1979). Ingestion rate of a selective deposit feeder in a complex mixture of particles; testing the energy-optimization hypothesis. Limnol. Oceanogr. 24: $867-874$

Elliot, J. M., Davison, W. (1975). Energy equivalents of oxygen consumption in animal energetics. Oecologia (Berl.) 19: 195-201

Epifanio, C. E., Ewart, J. (1977). Maximum ration of four algal diets for the oyster Crassostrea virginica Gmelin. Aquaculture 11: 13-29

Foster-Smith, R. L. (1975a). The effect of concentration of suspension and inert material on the assimilation of algae by three bivalves. J. mar. biol. Ass. U. K. 55: 411-418

Foster-Smith, R. L. (1975b). The effect of concentration of suspension on the filtration rates and pseudofaecal production for Mytilus edulis L., Cerastoderma edule (L.) and Venerupis pullastra (Montagu). J. exp. mar. Biol. Ecol. 17 : $1-22$

Gábbott, P. A. (1975). Storage cycles in marine bivalve molluscs: a hypothesis concerning the relationship between glycogen metabolism and gametogenesis. In: Barnes, $\mathrm{H}$. (ed.) Proc. 9th Europ. Mar. Biol. Symp. Aberdeen University Press, Aberdeen, p. 191-211

Gabbott, P. A. (1976). Energy metabolism. In: Bayne, B. L. (ed.) Marine mussels, International Biological Programme, Vol. 10. Cambridge University Press, Cambridge, p. 293-356

Gabbott, P. A. (1983). Developmental and seasonal metabolic activities in marine molluscs. In: Hochachka, P. W. (ed.) The Mollusca, Vol. 1. Academic Press, New York, p. 165-217

Gabbott, P. A., Bayne, B. L. (1973). Biochemical effects of temperature and nutritive stress on Mytilus edulis L. J. mar. biol. Ass. U. K. 53: 269-286

Gabbott, P. A., Cook, P. A., Whittle, M. A. (1979), Seasonal changes in glycogen synthase activity in the mantle tissue of Mytilus edulis L. Regulation by tissue glucose. Biochem. Soc. Trans, 7: 895-896

Gerdes, D. (1983). The Pacific oyster Crassostrea gigas Part I. Feeding behaviour of larvae and adults. Aquaculture 31: 195-219

Giese, A. C. (1959). Comparative physiology. Annual reproductive cycles of marine invertebrates. Ann. Rev. Physiol. 21: $547-576$

Giese, A. C. (1966). Lipids in the economy of marine invertebrates. Physiol. Rev. 46: 244-298

Giese, A. C. (1969). A new approach to the biochemical composition of the mollusc body. Oceanogr. mar. Biol. A. Rev. 7: 175-229

Gleit, C. E., Holland, W. D. (1962). Use of electrically excited oxygen for the low temperature decomposition of organic substances. Analyt. Chem. 34: 1454-1457

Gnaiger, E. (1983). Calculation of energetic and biochemical equivalents of respiratory oxygen consumption. In: Gnaiger, E., Forstner, H. (ed.) Polarographic oxygen sensors: aquatic and physiological applications, Appendix C. Springer-Verlag, Berlin, p. 336-345

Gnaiger, E., Bitterlich, G. (1984). Proximate biochemical composition and caloric content calculated from elemental CHN analysis: a stoichiometric concept. Oecologia (Berl.) 62: $289-298$

Goromosova, S. A., Tamozhnyaya, V. A. (1980). Seasonal dynamics of enzymes of transamination in tissues of Black Sea mussels. Biol. Morja, Vladiv. 2: 62--68

Griffiths, R. J. (1977). Reproductive cycles in littoral populations of Choromytilus meridionalis $(\mathrm{Kr})$ and Aulocomya ater (Molina) with a quantitative assessment of gamete production in the former. J. exp. mar. Biol. Ecol. 30: 53-71

Griffiths, R. J. (1980a). Filtration, respiration and assimilation in the black mussel Choromytilus meridionalis. Mar. Ecol. Prog. Ser. 3: 63-70

Griffiths, R. J. (1980b). Natural food availability and assimilation in the bivalve Choromytilus meridionalis. Mar. Ecol. Prog. Ser. 3: 151-156

Hawkins, A. J. S., Bayne, B. L. (1984). Seasonal variation in the balance between physiological mechanisms of feeding and digestion in Mytilus edulis (Bivalvia: Mollusca). Mar. Biol. 82: 233-240

Hawkins, A. J. S., Bayne, B. L., Clarke, K. R. (1983). Coordinated rhythms of digestion, absorption and excretion in Mytilus edulis. (Bivalvia: Mollusca). Mar. Biol. 74: $41-48$

Ivlev, V. S. (1961). Experimental ecology of the feeding of fishes. Yale University Press, Connecticut

Jørgensen, C. B. (1949). The rate of feeding by Mytilus edulis in different kinds of suspension. J. mar. biol. Ass. U. K. 28: 33-344

Kinne, O. (1970). Temperature - animals - invertebrates. In: Kinne, O. (ed.) Marine ecology, Vol. 1, Environmental factors, Part 1. Wiley-Interscience, London, p. 407-514

Kiørboe, T., Møhlenberg, F., Nøhr, O. (1980). Feeding, particle selection and carbon absorption in Mytilus edulis in different mixtures of algae and resuspended bottom material. Ophelia 19: 193-205

Kiørboe, T., Møhlenberg, F., Nøhr, O. (1981). Effect of sus- 
pended bottom material on growth and energetics in Mytilus edulis. Mar. Biol. 61: 283-288

Kleiber, M. (1961). The fire of life. An introduction to animal energetics. John Wiley and Sons, Inc., New York

Krüger, F. (1960). Zur Frage der Größenabhängigkeit des Sauerstoffverbrauchs von Mytilus edulis L. Helgoländer wiss. Meeresunters. 7: 125-198

Livingstone, D. R. (1975). A comparison of the kinetic properties of pyruvate kinase in three populations of Mytilus edulis L. from different environments. In: Barnes, H. (ed.) Proc. 9th Europ. Mar. Biol. Symp. Aberdeen University Press, Aberdeen, p. 151-164

Livingstone, D. R. (1981). Induction of enzymes as a mechanism for the seasonal control of metabolism in marine invertebrates: glucose-6-phosphate dehydrogenases from the mantle and hepatopancreas of the common mussel Mytilus edulis L. Comp. Biochem. Physiol. 69 B: 147-156

Livingstone, D. R., Clarke, K. R. (1983). Seasonal changes in hexokinase from the mantle tissue of the common mussel Mytilus edulis L. Comp. Biochem. Physiol. 74 B: 691-702

Lowe, D. M., Moore, M. N., Bayne, B. L. (1982). Aspects of gametogenesis in the marine mussel Mytilus edulis $\mathrm{L}$. J. mar. biol. Ass. U. K. 62: 133-145

Lubet, P. (1959). Recherches sur le cycle sexual et l'émission des gamètes chez les Mytilidae et les Pectinidae (Moll. Bivalves). Revue Trav. Off. (scient. tech.) Pêch. marit. 23: $387-548$

Maddock, L., Boalch, G. T., Harbour, D. S. (1981). Populations of phytoplankton in the western English Channel between 1964 and 1974. J. mar. biol. Ass. U. K. 61: 565-583

Mann, R. (1978). A comparison of morphometric, biochemical and physiological indexes of condition in marine bivalve molluscs. In: Thorp, J. H., Whitfield Gibbons, J. (ed.) Energy and environmental stress in aquatic systems. Technical Information Center, U.S. Department of Energy, p. 484-498

Navarro, J. M., Winter, J. E. (1982). Ingestion rate, assimilation efficiency and energy balance in Mytilus chilensis in relation to body size and different algal concentrations. Mar. Biol. 67: 255-266

Naylor, E. (1976). Rhythmic behaviour and reproduction in marine animals. In: Newell, R. C. (ed.) Adaptation to environment. Essays on the physiology of marine animals. Butterworths, London, p. 393-418

Newell, R. C. (1979). Biology of intertidal animals. Marine Ecological Surveys, Faversham, Kent

Newell, R. I. E., Bayne, B. L. (1980). Seasonal changes in the physiology, reproductive condition and carbohydrate content of the cockle Cardium (= Cerastoderma) edule (Bivalvia: Cardiidae). Mar. Biol. 56: 11-19

Newell, R. I. E., Hilbish, T. J., Koehn, R. K., Newell, C. J. (1982). Temporal variation in the reproductive cycle of Mytilus edulis L. (Bivalvia, Mytilidae) from localities on the east coast of the United States. Biol. Bull. mar. biol. Lab., Woods Hole 162: 299-310

Palmer, R. E. (1980). Behavioural and rhythmic aspects of filtration in the bay scallop, Argopecten irradians concentricus (Say), and the oyster, Crassostrea virginica (Gmelin). J. exp. mar. Biol. Ecol, 45: 273-295

Palmer, R. E., Williams, L. G. (1980). Effect of particle concentration on filtration efficiency of the bay scallop Argopecten irradians and the oyster Crassostrea virginica. Ophelia 19: 163-174

Pierce, R. J., Wissing, T. E. (1974). Energy cost of food utilization in the bluegill (Lepomis macrochirus). Trans. Am. Fish. Soc. 103: 38-45

Pieters, H., Kluytmans, J. H., Zandee, D. I. (1980). Tissue composition and reproduction of Mytilus edulis in relation to food availability Neth. J. Sea Res. 14: 349-361

Pieters, H., Kluytmans, J. H., Zurburg, W., Zandee, D. I. (1979). The influence of seasonal changes on energy metabolism in Mytilus edulis (L.). I. Growth rate and biochemical composition in relation to environmental parameters and spawning. In: Naylor, E., Hartnell, R. G. (ed.) Cyclic phenomena in plants and animals. Pergamon Press, Oxford, p. 285-292

Riisgard, H. U., Randlov, A. (1981). Energy budgets, growth and filtration rates in Mytilus edulis at different algal concentrations. Mar. Biol. 61: 227-234

Salonen, K., Sarvala, J., Hakala, I., Vilyanem, M. (1976). The relation of energy and organic carbon in aquatic invertebrates. Limnol. Oceanogr. 21: 724-730

Sastry, A. N. (1975). Physiology and ecology of reproduction in marine invertebrates. In: Vernberg, F. J. (ed.) Physiological ecology of estuarine organisms. University of South Carolina Press, Columbia, p. 279-299

Sastry, A. N. (1979). Pelecypoda (excluding Ostreidae). In: Giese, A. C., Pearse, J. S. (ed.) Reproduction of marine invertebrates, Vol. V, Molluscs: Pelecypods and lesser classes. Academic Press, New York, p. 113-292

Saunders, D. S. (1977). An introduction to biological rhythms. Biackie and Son Ltd., London

Schulte, E. H. (1975). Influence of algal concentration and temperature on the filtration rate of Mytilus edulis. Mar. Biol. 30: 331-341

Seed, R. (1976). Ecology. In: Bayne, B. L. (ed.) Marine mussels, International Biological Programme, Vol. 10. Cambridge University Press, Cambridge, p. 13-65

Seiderer, L. J., Davis, C. L., Robb, F. T., Newell, R. C. (1984). Utilization of bacteria as a nitrogen resource by the kelpbed mussel Choromytilus meridionalis Krauss. Mar. Ecol. Prog. Ser. 15: 109-116

Shafee, M. S. (1981). Seasonal changes in the biochemical composition and caloric content of the black scallop Chlamys varia (L.) from Lanveoc, Bay of Brest. Oceanol. Acta 4: 331-341

Skjoldal, H. R., Barkati, S. (1982). ATP content and adenylate energy charge of the mussel Mytilus edulis during the annual reproductive cycle in Lindåspollene, western Norway, Mar. Biol. 70: 1-6

Sokal, R. R., Rohlf, F. J. (1969). Biometry. The principle and practice of statistics in biological research. W. H. Freeman and Co., San Francisco

Soofiani, N. M., Hawkins, A. D. (1982). Energetic costs at different levels of feeding in juvenile cod, Gadus morhua L. J. Fish Biol. 21: 577-592

Theede, H. (1963). Experimentelle Untersuchungen über die Filtrierleistung der Miesmuschel Mytilus edulis L. Kieler Meeresforsch., Sonderh. 19: 20-41

Thompson, R. J. (1972). Feeding and metabolism in the mussel Mytilus edulis L. Ph. D. thesis, University of Leicester

Thompson, R. J. (1977). Blood chemistry, biochemical composition, and the annual reproductive cycle in the giant scallop, Placopecten magellanicus, from southeast Newfoundland. J. Fish. Res. Bd Can. 34: 2104-2116

Thompson, R. J. (1984). The reproductive cycle and physiological ecology of the mussel Mytilus edulis in a subarctic, non-estuarine environment. Mar. Biol. 79: 277-288

Thompson, R. J., Bayne, B. L. (1972). Active metabolism associated with feeding in the mussel Mytilus edulis L. J. exp. mar. Biol. Ecol. 9: 111-124.

Thompson, R. J., Bayne, B. L. (1974). Some relationships between growth, metabolism and food in the mussel, Mytilus edulis. Mar. Biol. 27: 317-326 
Vahl, O. (1978). Seasonal changes in oxygen consumption of the Iceland scallop (Chlamys islandica [O. F. Muiller]) from $70^{\circ} \mathrm{N}$. Ophelia 17: 143-154

Vahl, O., Davenport, J. (1979). Apparent specific dynamic action of food in the fish Blennius pholis. Mar. Ecol. Prog. Ser. 1: 109-113

Waldock, M. J., Holland, D. L. (1979). Seasonal changes in the triacylglycerol fatty acids of the mantle tissue of the mussel Mytilus edulis L. Biochem. Soc. Trans. 7: 898-900

Warren, C. E., Davis, G. E. (1967). Laboratory studies on the feeding, bioenergetics and growth of fish. In: Gerking, $\mathrm{S}$ D. (ed.) The biological basis of freshwater fish production. Blackwell Scientific Publications, Oxford, p. 175-214

Widdows, J. (1976). Physiological adaptation of Mytilus edulis L. to cyclic temperatures. J, comp. Physiol. 105: $115-128$

Widdows, J. (1978a). Combined effects of body size, food concentration and season on the physiology of Mytilus edulis. J. mar. biol. Ass. U. K. 58: 109-124

Widdows, J. (1978b). Physiological indices of stress in Mytilus edulis. J. mar. biol. Ass. U. K. 58: 125-142

Widdows, J., Bayne, B. L. (1971). Temperature acclimation of Mytilus edulis with reference to its energy budget. J. mar. biol. Ass. U. K. 51: $827-843$

Widdows, J., Bayne, B. L., Donkin, P., Livingstone, D. R., Lowe, D. M., Moore, M. N., Salkeld, P. N. (1981a). Measurement of the responses of mussels to environmental stress and pollution in Sullom Voe: a base-line study. Proc. R. Soc. Edinb. 80: 323-338

Widdows, J., Phelps, D. K., Galloway, W. (1981b). Measurement of physiological condition of mussels transplanted along a pollution gradient in Narragansett Bay. Mar. environ. Res. 4: 181-194

Widdows, J., Worrall, C., Fieth, P. (1979). Relationships between seston, available food and feeding activity in the common mussel Mytilus edulis L. Mar. Biol. 50: 195-207

Winberg, G. G. (1960). Rate of metabolism and food requirements of fishes. Fish. Res. Bd Can., Translation Ser. 194: $1-202$
Winter, J. E. (1969). Uber den Einfluß der Nahrungskonzentration und anderer Faktoren auf Filtrierleistung und Nahrungsausnutzung der Muscheln Arctica islandica und Modiolus modiolus. Mar. Biol. 4: 87-135

Winter, J. E. (1973). The filtration rate of Mytilus edulis and its dependence on algal concentration, measured by a continuous automatic recording apparatus. Mar. Biol. 22: 317-328

Winter, J. E. (1976). Feeding experiments with Mytilus edulis L. at small laboratory scale. II. The influence of suspended silt in addition to algal suspensions on growth. In: Persoone, G., Jaspers, E. (ed.) Proc. 10th Europ. Mar. Biol. Symp. Universa Press, Wetteren, p. 583-600

Winter, J. E. (1978). A review of the knowledge of suspension feeding in lamellibranchiate bivalves, with special reference to artificial aquaculture systems. Aquaculture 13: $1-33$

Winter, J. E., Langton, R. W. (1976). Feeding experiments with Mytilus edulis $\mathrm{L}$. at small laboratory scale. I. The influence of the total amount of food ingested and food concentration on growth. In: Persoone, G., Jaspers, E. (ed.) Proc. 10th Europ. Mar. Biol. Symp. Universa Press, Wette. ren, p. 565-581

Zandee, D. I., Holwerda, D. A., de Zwaan, A. (1980a). Energy metabolism in bivalves and cephalopods. In: Gilles, R. (ed.) Animals and environmental fitness, Vol. 1. Pergamon Press, Oxford, p. 185-206

Zandee, D. I., Kluytmans, J. H., Zurburg, W., Pieters, H. (1980b). Seasonal variations in biochemical composition of Mytilus edulis with reference to energy metabolism and gametogenesis. Neth. J. Sea Res. 14: 1-29

Zurburg, W., Kluytmans, J. H., Pieters, H., Zandee, D. I. (1979). The influence of seasonal changes on energy metabolism in Mytilus edulis L. II. Organ specificity. In: Naylor, E., Hartnoll, R. G. (ed.) Cyclic phenomena in marine plants and animals. Pergamon Press, Oxford, p. $293-300$ 